\title{
Typographical revision and language option in the Evangelium from Snagov, 1697
}

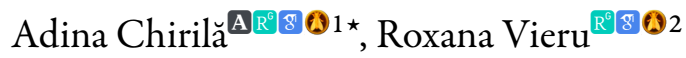 \\ ${ }^{1}$ Faculty of Letters, History and Theology, West University, Bd. Vasile Pârvan 4, 300223 Timișoara, Romania \\ ${ }^{2}$ Faculty of Letters, "Alexandru Ioan Cuza" University, Bd. Carol I 11, 700506 Iași, Romania
}

\section{Article info}

History:

Received August 6, 2021

Accepted August 8, 2021

Published August 18, 2021

Key words:

philology

text editing

comparative analysis

\begin{abstract}
The new edition of the Evangelium printed in Snagov, in 1697 (E 1697) is distinguished from the previous ones by two aspects: a) structure of the text because the accuracy of the biblical references in relation to the moments of the church year is restored and ensured, thus making the correlation between the liturgical book of ecclesiastical use and the archetype-text, the New Testament, divided into chapters; b) linguistic option of the editor, which specifically and consistently aims at the regime of verbal tenses, i.e., the change of the forms of the simple perfect of the basic edition (E 1693) into forms of compound perfect.

Typographical and linguistic differences identified between E 1697 в[ucharest], Е 1697 I[ași] and E $1697 \mathrm{v}$ [ienna], of the eleven copies of the book, preserved to this day, indicate the unfolding of some stages in the realization of the edition, a complex and nonlinear editorial and typographical behaviour.
\end{abstract}

\section{E 1697}

The princely printing house installed in Snagov produced in 1697 five books, one of which was in the Romanian language. Its full title is $S f[\hat{\imath}] n t a$ și $d[u]$ mnezeiasca Evanghelie, cu voia prea luminatului și inălțatului D[o]mn și oblăduitoriu a toată Țara Rumânească, Io Constandin B. Voievodși cu porunca purtătoriului Pravoslaviei prea sf[i]nțitul Chir Theodosie, Mitropolitul a toatei Țări Rumânești și exarhu plaiurilor. Acum a doa oară tipărită și diortosită, mai cu multă nevoințăa în sf[î̀nta Mănăstire in Sneagov, la anul de la spăseniia lumii 1697, de smeritul întru iermonabi Anthim Ivireanul (Ir) (cf. BRV I, p. 343-344).

The specification regarding the order of this book in a number of similar typographical appearances probably refers to the first book with Romanian text that Antim Ivireanul worked on, as a printer: Evanghelia greco-română [the Greek-Romanian Gospel] published in 1693 in Bucharest, by the efforts of Șerban Greceanu and Athanasie Moldoveanul.

Actually, in order to produce Evanghelia of 1697, Antim Ivireanul could have used, as a basic-text, one of the two previous versions: the one from 1682, which, in terms of structure, departs from the Slavonic model of the tetraevangelium from the previous century, being conceived, according to its preface, "precum umblă cea elinească și întru toate aseamene, după orînduiala Besearecii Răsăritului" ["as the Greek one goes, and in all likeness, according to the order of the Church of the East"] (E 1682, [III ${ }^{\mathrm{r}}$ ) and the bilingual one from 1693, which resumes, on the Romanian column, the previous text, keeping its organization. Since Antim Ivireanul himself had taken part in the making of the 1693 edition, one can safely assume that Antim used it in the making of the new version of 1697, operating, as the title suggests, some revisions; however, the collation of the three editions reveals situations and differences that can be explained only by the return of the diortositor / printer to the older text, from 1682.

^Email address: chiriladina@yahoo.com. 


\section{Emendations}

The correctness alluded to in the title of the 1697 book concerned two aspects: a) the structure of the content and $\mathrm{b}$ ) the linguistic form.

In the first regard, a), the differences between E 1697 and E 1693 (and E 1682) are, most of the time, of detail, restoring and ensuring the accuracy of the respective moment of the church year and the accuracy of the biblical references. Distinctly from previous achievements ${ }^{1}$, in $\mathrm{E} 1697$ the correlation is made between the liturgical book of church use and the text-archetype, the New Testament, divided into chapters:

"Cade-se a ști că la E[va]ng[he]lia aceasta nu s-au pus zacealele pre cum au fost întîi, ce capetele: pentru ca să poată afla fieștecine mai lesne ce i-ar trebui la Tetravanghel. Și pre unde iaste steaoa aceasta [ ], să nu gîndească neștine că s-au pus în toate locuri pentru soroacă de săvîrșit, ce pentru unirea stihurilor den Tetravanghel." (E 1697, [III] $]^{\mathrm{r}}$.

Rarely, the reference to the biblical text is wrong: in "Luni, a doaosprăzeace săptămînă după Rusalii, de la Matthei, cap. 1" (E 1697, 43 ${ }^{\mathrm{r}}$ ), the biblical pericope used is, in fact, from Mark (1, 9-15)—a mistake compared to previous versions E 1693 (94) and E $1682\left(41^{\mathrm{v}}\right)$.

A major correction compared to the 1693 edition is the completion of the text with the evangelical fragments corresponding to Monday, Tuesday, Wednesday, Thursday and Friday of the seventeenth week after Pentecost of the church year: in E 1693, "Duminica a 16" [the $16^{\text {th }}$ Sunday] is immediately followed by "Sîmbătă a 17" [the $17^{\text {th }}$ Saturday] (116); in E 1682, the omisson does not exist $\left(51^{\mathrm{r}}-52^{\mathrm{v}}\right)$. It seems that Antim returns to the original source when some need arises.

Regarding the linguistic form of the text, $\mathrm{b}$ ), it is noted that the new editor was especially concerned with the regime of verbal tenses. The other changes observed at the grammatical and lexical level do not show, judging by the inconsistency with which they were generally made, a particular concern in the direction of the renewal of language and expression. A major exception is the intervention aimed at changing the forms of the simple perfect from the basic edition (be it $\mathrm{E} 1693$ or $\mathrm{E} 1682$ - the differences in this regard are minimal between the two) in compound perfect forms. The comparison between the 1697 version, "diortosită mai cu multă nevoință" $\left(\left[\mathrm{I}^{\mathrm{r}}\right]\right)$, and that of 1693, on three corresponding fragments of text (see infra ${ }^{2}$ ) highlights a consistent approach in this regard: nu șăzură - nu aușăzut; să sui -s-au suit; găsi - au găsit; scoasă - au scos; răsturnă - au răsturnat; etc.

E 1693

Vineri după Paști. De la Ioan. 7 [7] [John, 2]
E 1697

Vineri după Paști, în sărbători, de la Ioann, cap. 2 $\left[3^{\mathrm{v}}-4^{\mathrm{r}}\right][\mathrm{John}, 2]$
În vreamea aceaia veni I[su]s în Capernaum însuși, și muma lui și frații lui și ucenicii lui; și acolo nu șăzură zile multe, că era aproape Paștile jidovilor. Și să sui I su]s în Ierusalim. Și găsi în besearecă pre ceia ce vindea boi și oi și porumbi și pre schimbătorii de bani șezînd. Și făcînd biciu de ștreanguri, pre toți îi scoasă din besearecă, oile și boii; și răsipi banii schimbătorilor şi measele le răsturnă. Și celora ce vindea porumbi zise: „Luați aceastea de aicea și nu faceți casa Tatălui mieu casă de neguțătorie.” Și-și adusără aminte ucenicii Lui că iaste scris: „Dragostea casii Tale mă mîncă pre mine.” Dec[i] răspunsără jidovii și zisără lui: „Ce semn arăți
În vreamea aceaia veni I[su]s în Capernaum însuși, și muma lui și frații lui și ucenicii lui; și acolo nu au șezut zile multe. Și era aproape Paștile jidovilor; și s-au suit I $[$ su]s în Ierusalim. Și au găsit în besearecă pre ceia ce vindea boi și oi și porumbi și pre schimbătorii de bani șezînd. Și făcînd bici de ștreanguri, pre toți $i$-au scos den besearecă, oile și boii; și răsipi banii schimbătorilor și measele le-au răsturnat. Și celora ce vindea porumbi le-au zis: „Luați aceastea de aicia și nu faceți casa Tatălui mieu casă de neguțătorie." Și-ș aduseră aminte ucenicii Lui că iaste scris: „Dragostea casii Tale mă mîncă pre mine.” Răspuns-au jidovii și i-au zis lui: „Ce semn arăț

\footnotetext{
${ }^{1}$ For an overview of the history of the Evangelium's use in the Romanian culture, see Pavel (2012, p. 13-28).

${ }^{2}$ In the passages presented in parallel, the divergent forms (simple perfect $v$ s. compound perfect, or, more rarely, pluperfect) are written in italics.
} 
noaă, de faci aceastea?”. Răspunse I[su]s și zise lor: "Spargeți beseareca aceasta și în trei zile o voiu rădica." Și ziseră jidovii: „În patruzeci și șase de ani să zidi beseareca aceasta și tu în trei zile vei să o rădici?’. Iară El zicea de beseareca trupului său. Deci cînd să sculă den morți ș-au adus aminte ucenicii lui că aceasta zicea lor și crezură scripturii și cuvîntului carele zisease I[su $]$ s.

E 1693

Luni, săptămîna a dooa. De la Ioan. 6 [9] [John, 2]

În vreamea aceaia nuntă să făcu în Cana Galileii și era muma lui I $[\mathrm{su}] \mathrm{s}$ acolo. Şi $f u$ chemat I $[\mathrm{su}] \mathrm{s} \mathrm{şi} \mathrm{uc[e]nicii}$ lui la nuntă. Și, sfirșindu-se vinul, zise muma lui I [su]s cătră dînsul: „Vin n-au.” Zise ei I[su]s: „Ce e mie și ție, muiare? Încă n-au venit ceasul mieu." Zise muma lui slugilor: „Orice ar zice voaă, faceți!”. Și era acolo șase vase de piatră, stînd după curățeniia jidovilor, care lua cîte doao sau trei veadre. $Z$ ise lor I[su $] \mathrm{s}$ : „Umpleți vasele de apă." Și le implură pînă sus. Și zise lor: „Turnați acum și aduceți nunului.” Și-i adusără. Și după ce gustă nunul apa ce să făcuse vin (și nu știia de unde iaste, iară slugile carii turnase apa știia), strigă pre ginere nunul. Și zise lui: „Tot omul întîiu vinul cel bun pune şi, deaca să îmbată, atunce cel mai prost. Iară tu ai ținut vinul cel bun pînă acum." Aceasta făcu începătură seamnelor I [su $]$ s în Cana Galileii. Și arătă slava sa și crezură întru el ucenicii lui.

E 1693

$\mathrm{E}[\mathrm{va}] \mathrm{ng}[\mathrm{he}] \mathrm{lia}$ a opta a sf[i] ntelor patime. De la Luca. 114 [264-265] [Luke, 23]

In vreamea aceaia ducea cu I[su]s şi alți doi făcători de rău împreună cu el să-i piarză. Și deaca veniră la locul ce să chiamă al Căpăținii, acolo răstigniră pre el și pre făcătorii de rău: unul de-a direapta şi altul de-a stînga. Iară I[su]s zicea: „Părinte, iartă lor, că nu știu ce fac!”. Și împărțind veșmintele lui, puseră sorți. Și sta nărodul privind. Și-ș bătea joc și boiarii împreună cu ei, zicînd: „Pre alții au mîntuit; mîntuiască-se pre sine, de iaste acesta $\mathrm{H}[$ risto]s cel ales al lui D[u]mnezău." Și-și bătea joc și slujitorii, apropiindu-să și oțet aducîndu-i lui și zicînd: „De ești tu împăratul jidovilor, mîntuiaște-te pre tine.” Și era și scrisoare scrisă deasupra lui, cu slove ellinești și rîmlenești și jidovești: „Acesta iaste împăratul jidovilor.” Iară unul din cei răstigniți făcători de rău huliia pre dînsul, zicînd: „De ești tu $\mathrm{H}$ [risto]s, mîntuiaște-te pre tine și pre noi!”. Iară răspunzînd celalalt, certa pre el, zicînd: „Nu te temi tu de $\mathrm{D}[\mathrm{u}]$ mnezău, că într-aceaiaș osîndă ești? Și noi, pre noao, de faci aceastea?”. Răspuns-au I[su]s și le-au zis lor: „Spargeți beseareca aceasta și în trei zile o voiu rădica.” Și ziseră jidovii: „În patruzeci și șase de ani s-au zidit beseareca aceasta şi tu în trei zile vei să o rădici?”. Iară El zicea de beseareca trupului său. Deci cînd să sculă den morți ș-au adus aminte ucenicii că aceasta zicea lor și au crezut scripturii și cuvîntului carele zisease I $[\mathrm{su}] \mathrm{s}$.

\section{E 1697}

Luni, în săptămîna a dooa după Paști, de la Ioann, cap. $2\left[4^{\mathrm{v}}-5^{\mathrm{r}}\right][\mathrm{John}, 2]$

În vreamea aceaia nuntă $s$-au fãcut în Cana Galileii și era muma lui I[su]s acolo. Și au fost chiemat I[su $]$ s și ucenicii lui la nuntă. Și, sfîrșindu-se vinul, au zis muma lui I [su ]s cătră dînsul: „Vin n-au.” Zis-au e<i $>\mathrm{I}[\mathrm{su}] \mathrm{s}$ : „Ce e mie și ție, muiare? Încă n-au venit ceasul mieu.” Zis-au muma lui slugilor: „Orice ar zice voao, să faceți!’. Și era acolo șase vase de piatră, puse după curățeniia jidovilor, carele lua cîte doao sau trei veadre. Zis-au lor I[su]s: „Umpleți vasele de apă.” Și le-au umplut pînă sus. Și le-au zis lor: „Turnați acum și aduceți nunului." Și i-au adus. Și după ce au gustat nunul apa ce să făcuse vin (și nu știia de unde iaste, iară slugile carii turnase apa știia), strigat-au pre ginere nunul. Și i-au zis lui: „Tot omul întîi vinul cel bun pune și, deaca să îmbată, atuncea cel mai prost. Iară tu ai ținut vinul cel bun pînă acum.” Aceasta au făcut începătură seamnelor I[su]s în Cana Galileii. Și ș-au arătat slava sa și au crezut întru el ucenicii lui.

\section{E 1697}

$\mathrm{E}[\mathrm{va}] \mathrm{ng}[\mathrm{he}]$ lia a opta a sf[i] ntelor patime, de la Luca, cap. $23\left[122^{\mathrm{v}}-123^{\mathrm{r}}\right][$ Luke, 23]

În vreamea aceaia ducea împreună cu I[su]s și alți doi tîlhari să-i piarză. Și deaca au venit la locul ce să chiamă al Căpăținilor, acolo l-au răstignit pre el și pre tîlhari: unul de-a direapta și altul de-a stînga. Iară I $[$ su $]$ s zicea: „Părinte, iartă-le lor, că nu știu ce fac!”. Iară cei ce împărțiia hainele lui au aruncat sorți. Și sta norodul de priviia. Și-ș bătea joc de dînsul și boiarii împreună cu dînşii, zicînd: „Pre alții au mîntuit; mîntuiască-se și pre sine, de iaste acesta $\mathrm{H}[$ risto]s cel ales al lui $\mathrm{D}[\mathrm{u}]$ mnezău." Rîdea-ș de el și slujitorii, apropiindu-să și oțet aducîndu-i lui și zicînd: „De ești tu împăratul jidovilor, mîntuiaște-te pre tine singur.” Era și scrisoare scrisă deasupra lui, cu slove ellinești și rîmlenești și ovreești: „Acesta iaste împăratul jidovilor.” Iară un tîlhariu din cei răstigniți huliia pre dînsul, zicînd: „De ești tu H[risto]s, mîntuiaște-te pre tine și pre noi!”. Iară răspunzînd celalalt, l-au certat pre el, zicînd: „Nu te temi tu de D[u]mnezău, că întru aceaiaș osîndă ești? Și 
direptul, pentru că vreadnice celor ce-am făcut luom; iară acesta nice un rău n-au făcut.” Și zicea lui I[su]s: „Pomeneaște-mă, D[oa]mne, cînd vei veni întru împărățiia ta!”. Atuncea zise I[su]s lui: „Adevăr zic ție: astăzi cu mine vei fi în raiu.” Și era ca la al șaselea ceas; și întunearec $f u$ preste tot pămîntul pînă la al noaolea ceas. Și să întunecă soarele și să rupse catapeteazma besearecii prin mijloc. Și, strigînd cu glas mare I $[\mathrm{su}] \mathrm{s}$, zise: „Părinte, în mîinile tale dau duhul mieu.” Și, aceastea zicînd, răposă. Iară văzînd sutaşul ce $f u$, slăvi pre $\mathrm{D}[\mathrm{u}]$ mnezău, zicînd: „Adevărat, omul acesta dirept au fost!”. Și toată mulțimea carea venise împreună la privirea aceasta, văzînd cealea ce fură, bătîndu-ș piepturile lor să întoarseră. Și sta toți cunoscuții lui de departe și muierile carele venisă după el din Galilea, văzînd aceastea. noi, cu direptul, căci ceale vreadnice după faptele noastre luom; iară acesta nice un rău n-au făcut." Și au zis lui I [su $]$ s: „Pomeneaşte-mă, D[oa]mne, cînd vei veni întru împărățiia ta!”. Și au zis I[su]s lui: „Adevăr zicu ție: astăzi împreună cu mine vei fi în rai.” Și era ca la al șaselea ceas; și întunearec $s$-au făcut preste tot pămîntul pînă la al noaolea ceas. Și s-au întunecat soarele și s-au rupt catapeteazma besearecii prin mijloc. Şi, strigînd cu glas mare I[su ]s, au zis: „Părinte, în mîinile tale dau sufletul mieu.” Și, aceastea zicînd, au răpăosat. Iară văzînd sutașul cealea ce să făcuse, au slăvit pre D[u]mnezău, zicînd: „Cu adevărat, omul acesta dirept au fost!”. Și tot norodul ce fusease împreună la priveala aceaia, văzînd cealea ce să făcuse, bătîndu-ș piepturile sale, s-au întors. Și sta toți cunoscuții lui de departe și muierile carele venise după el din Galilea, văzînd aceastea.

In most of the situations that, in $\mathrm{E} 1693$, present constructions with the simple perfect seen in the above fragments, the verbal form was replaced with a compound perfect-sometimes with the option for another verb: puseră $(\mathrm{E} 1693,264)$ - au aruncat $\left(\mathrm{E} 1697,122^{\mathrm{v}}\right), f u(\mathrm{E} 1693,265)$ - s-au făcut $\left(\mathrm{E} 1697,122^{\mathrm{v}}\right)$ in the process of making the $\mathrm{E} 1697$. The action, with its high degree of consistency, is characteristic of the entire text and makes the narrative sequences of $\mathrm{E} 1697$, unlike $\mathrm{E} 1693$, have the compound perfect as prototyping verbal tense.

The effort to remove the forms of simple perfect is, on the one hand, in accordance with the tendency signaled, in general, for the $17^{\text {th }}-18^{\text {th }}$ centuries, of restricting its area of circulation, in the spoken language, to Oltenia, Banat and Crișana; on the other hand, however, it runs counter to the habit of continuing to be used intensively in written texts (Frâncu, 2009, p. 306). The transition from the simple perfect to the compound perfect is not a general and blind rule in the process of editing, as can be seen in two cases present in the excerpted texts, where the simple perfect has been replaced by the pluperfect, for rendering a process located before another process in the past: $f u(\mathrm{E} 1693,265)$ - să făcuse (with a change of number as well, E 1697, 122 $\left.2^{\mathrm{v}}\right)$, fură $(\mathrm{E} 1693,265)$ - să făcuse $\left(\mathrm{E} 1697,123^{\mathrm{r}}\right)$. The diversity of linguistic choices regarding the regime of the verbal forms of the past tense, greater than that recorded in the basic edition, emphasizes the different temporal depths of the narrative and of the discursive plans, perceived and controlled by the editor. This is more evident in situations where two forms of simple perfect that are close or in immediate succession have different resolutions in the new edition, according to the chronology of the narrated events:

“văzînd sutașul ce fu, slăvi pre D[u]mnezău” (E 1693, 265) - „văzînd sutașul cealea ce să făcuse, au slăvit pre $\mathrm{D}[\mathrm{u}]$ mnezău” (E 1697, 123 $\mathrm{r}$ );

“Și toată mulțimea carea venise împreună la privirea aceasta, văzînd cealea ce fură, bătîndu-ș piepturile lor să intoarseră." (E 1693, 265) - „S,i tot norodul ce fusease împreună la priveala

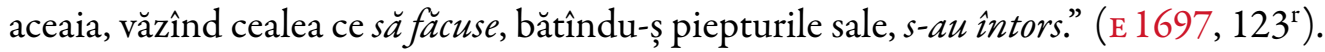

The places where the simple perfect form is preserved are, by comparison, much rarer.

\section{Printing variants}

That we are faced with a programmed intention to emendate the text in linguistic terms is a fact that is discovered not only after comparing the successive editions of the book, but also in the research of the copies of the 1697 edition, existing today. 
There are 11 copies registered in Catalogul colectiv al cărții vechi românești (see Evanghelie. Snagov, 1697). Of these, we were able to compare in detail three: a copy held by the Library of the Romanian Academy, Bucharest, inv. 467 (further, for the discussion on the linguistic and typographical differences between them, E 1697 B); a copy owned by the Library of the Romanian Academy, Iaşi, inv. n.a. (E 1697 I); and the copy in the Collection of Old Manuscripts and Prints of the Austrian National Library, inv. 22.C.11 (E $1697 \mathrm{v})$. The three copies are not absolutely identical: there are differences between them of typographical and linguistic nature, that indicate the development of some stages in the realization of the edition. The differences concerning the regime of the verbal tenses, in this case, the emendation of the simple perfect from the basic edition (E 1682/1693) are recorded in portions of text printed on $1^{\mathrm{r}-\mathrm{v}}$ and $4^{\mathrm{r}-\mathrm{v}}$ :

E 1693

luminează și întunearecul pre ia $n u$

o cuprinse. (1)

Că leagea prin Moisii fu dată, iară

darul pren $\mathrm{I}[\mathrm{su}]_{\mathrm{s}} \mathrm{H}[$ risto $]$ s fu. (2)

Și-l întrebară: „Dară Cine ești? Au

doară tu ești Ilie?” (3)

Deci ziseră lui: „Cine ești?...” (3)

Deci cînd să sculă din morți ş-au adus aminte ucenicii lui că aceasta zicea lor şi crezură scripturii și cuvîntului carele zisease I[su]s. (7)

Și să bucurară uc[e]nicii văzînd pre
$\mathrm{D}[\mathrm{o}] \mathrm{mnul}(8)$

Și lumina întru întunearec

E 1697 I

Și lumina întru întunearec

luminează și întunearecul nu o cuprinse. $\left(1^{\mathrm{r}} / 1\right)$

Că leagea prin Moisii au fost dată, iară darul și adevărul prin I[su $] s$ $\mathrm{H}[$ risto $] \mathrm{s} f u .\left(1^{\mathrm{v}} / 1\right)$

Și-l intrebară: „Cine ești? Au doară tu ești Ilie?” (1 $\left.1^{\mathrm{v}} / 2\right)$

Deci ziseră lui: „Cine ești?...” $\left(1^{\mathrm{v}} / 2\right)$

Deci cînd să sculă den morți ș-au adus aminte ucenicii că aceasta zicea lor și crezură scripturii și cuvintului carele zisease I[su]s. $\left(3^{\mathrm{v}} / 2-4^{\mathrm{r}} / 1\right)$

Iară Thoma, unul din cei doisprăzeace, care să chiamă Geamăn, nu era cu ei cînd veni I[su]s. (8)

Iară el zise lor: „De nu voiu

vedea..." (8)

Zise lui I[su]s: „Deaca mă văzuși, crezuși..." (9)

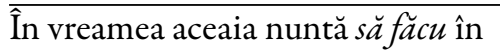
Cana Galileii (9) Și-i aduseră (9) după ce gustă nunul apa ce să făcuse $\operatorname{vin}(9)$
Și să bucurară ucenicii văzînd pre Domnul $\left(4^{\mathrm{r}} / 2\right)$

Iară Thoma, unul den cei
doisprăzeace, care să chiamă Geamăn, nu era cu ei cînd veni I $[\mathrm{su}]$ s. $\left(4^{\mathrm{v}} / 1\right)$

Iară el zise lor: „De nu voiu
vedea..." $\left(4^{\mathrm{v}} / 1\right)$

Zise lui I[su]s: „Deaca mă văzuși, crezuși...” (4v $/ 1)$

În vreamea aceaia nuntă să făcu în Cana Galileii $\left(4^{\mathrm{v}} / 2\right)$ Și-i aduseră $\left(4^{\mathrm{v}} / 2\right)$ după ce gustă nunul apa ce să făcuse $\operatorname{vin}\left(4^{\mathrm{v}} / 2\right)$
E $1697 \mathrm{~V} / \mathrm{B}$

Și lumina întru întunearec

luminează şi întunearecul nu o au cuprins. $\left(1^{\mathrm{r}} / 1\right)$

Că leagea prin Moisii au fost dată, iară darul și adevărul prin I[su $] s$ $\mathrm{H}[$ risto $]$ s au fost. $\left(\mathrm{I}^{\mathrm{v}} / 1\right)$

Și l-au intrebat: „Cine ești? Au doară tu ești Ilie?” (1v/2) Deci au zis lui: „Cine ești?...” $\left(1^{\mathrm{v} / 2)}\right.$

Deci cînd să sculă den morți ș-au adus aminte uc[e]nicii că aceasta zicea lor şi au crezut scripturii și cuvîntului carele zisease I[su]s. $\left(3^{\mathrm{v}} / 2-4^{\mathrm{r}} / 1\right)$

Și s-au bucurat ucenicii văzînd pre Domnul $\left(4^{\mathrm{r}} / 2\right)$

Iară Thoma, unul den cei
doisprăzeace, care să chiamă Geamăn, nu era cu ei cînd au venit $\mathrm{I}[\mathrm{su}] \mathrm{s} .\left(4^{\mathrm{v}} / 1\right)$

Iară el le-au zis lor: „De nu voiu
vedea..." (4 $\left.4^{\mathrm{v}} / 1\right)$

Zis-au I[su]s lui: „Deaca mă văzuşi,

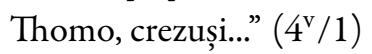

În vreamea aceaia nuntă $s$-au făcut in Cana Galileii $\left(4^{\mathrm{v}} / 2\right)$ Şi i-au adus. $\left(4^{\mathrm{v}} / 2\right)$ după ce au gustat nunul apa ce să făcuse vin $\left(4^{\mathrm{v}} / 2\right)$

Belonging to the edition $\mathrm{E} 1697$, the copy $\mathrm{E} 1697$ I records, as we have indicated above, the strong tendency to emend the forms in the paradigm of the verbal past; but it presents a number of simple perfect forms that do not appear in the $\mathrm{E} 1697 \mathrm{~V}$ and $\mathrm{E} 1697 \mathrm{~B}$, but which correspond to the forms of the base edition at the places concerned. It is possible that, working on the text, the editor / printer has made a first wave of changes, printing accordingly the typographic sheet, with a text shape visible in E 1697 I; to a reassessment of what had been done until then, probably under the influence of a clearer and clearer conviction regarding the justice of this emendatory practice, the editor returns to the text, corrects it additionally (or reconstructs the page) and reprints accordingly the typographic sheet, with a form of the text visible in the $\mathrm{E} 1697 \mathrm{~V}$ and $\mathrm{E} 1697 \mathrm{~B}$; and then continues in a manner that, until the end, satisfies him in terms of 
c) whole word $v$ s. shorthand/letter written above the row:

\begin{tabular}{|c|c|}
\hline E 1697 I & E $1697 \mathrm{~V} / \mathrm{B}$ \\
\hline mósıa $\left(1^{\mathrm{v}} / 2, \mathrm{r} .20\right)$ & แช่ง \\
\hline $1 \mathrm{t} \gamma \mathrm{\gamma} \dot{\mathrm{H}}\left(4^{\mathrm{r}} / 2, \mathrm{r} .26\right)$ & 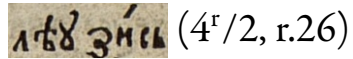 \\
\hline
\end{tabular}

d) different typographical organization of the row:

\begin{tabular}{|c|c|}
\hline E 1697 I & E $1697 \mathrm{~V} / \mathrm{B}$ \\
\hline 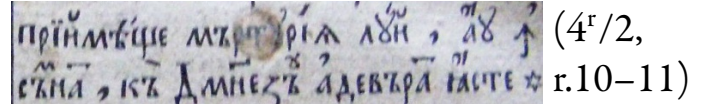 & 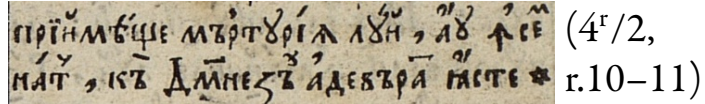 \\
\hline
\end{tabular}

e) differences in the involvement of diacritic signs and/or graphic signs without phonetic value:

\begin{tabular}{|c|c|}
\hline E 1697 I & E $1697 \mathrm{~V} / \mathrm{B}$ \\
\hline $\sin 18 \operatorname{siT}^{2 y}\left(1^{\mathrm{v}} / 1, \mathrm{r} .7\right)$ & 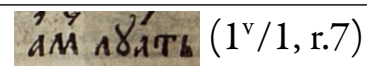 \\
\hline фіннй $\left(1^{\mathrm{v}} / 1, \mathrm{r} .19\right)$ & 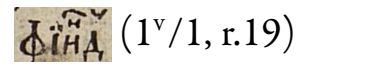 \\
\hline
\end{tabular}

Finally, in the binding of the book are used all the typographical versions of the text, which determines the production and putting into circulation of distinct copies 5 .

The fact that the amendments do not concern the entire typographical achievement (they can be observed, regardless of their nature-see also infra-, up to $7^{\mathrm{r}}$ ) leads us to consider unfounded the introduction in our discussion, for the edition E 1697, the notions of initial circulation, to which E 1697 I (and, probably, others) would belong, and second circulatio, etc., to which other specimens would belong. It is however certain that the objects E 1697 I, E $1697 \mathrm{~V}$ and E $1697 \mathrm{~B}$, arising from the entire printing activity, reflect distinct moments in the text editing process.

Those indicated so far place the execution of sheets $1^{\mathrm{r}-\mathrm{v}}$ and $4^{\mathrm{r}-\mathrm{v}}$ of the copy $\mathrm{E} 1697 \mathrm{I}$ in the precedence of that of the corresponding sheets of $\mathrm{E} 1697 \mathrm{~V}$ and B. However, the chronological conjecture must be modified for the sheets $2^{\mathrm{r}-\mathrm{v}}$ and $3^{\mathrm{r}-\mathrm{v}}$, where the differences put the $\mathrm{E} 1697 \mathrm{~V}$ copy in opposition to the E 1697 I and B copies. Here also, they are rather typographical and graphic:

a) the use of a different model of letter:

\begin{tabular}{|c|c|}
\hline E $1697 \mathrm{~V}$ & E 1697 I/B \\
\hline 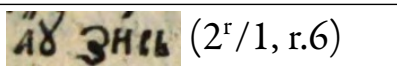 & 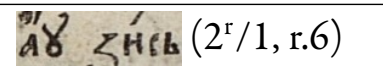 \\
\hline AÝ́E(TA $\left(2^{\mathrm{r}} / 2, \mathrm{r} .31\right)$ & Bั'́⿴囗十 $\left(2^{\mathrm{r}} / 2, \mathrm{r} .31\right)$ \\
\hline 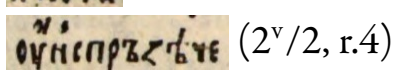 & 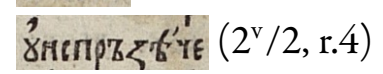 \\
\hline
\end{tabular}

b) the use of a different letter but with the same phonetic value:

\begin{tabular}{|c|c|}
\hline E $1697 \mathrm{~V}$ & E 1697 I/B \\
\hline Aápz $\left(2^{r} / 1\right.$, r.9) & A,APb $\left(2^{r} / 1, r .9\right)$ \\
\hline उHYYE $\left(2^{\mathrm{r}} / 1, \mathrm{r} .2\right)$ & दитн $\left(2^{\mathrm{r}} / 1, \mathrm{r} .2\right)$ \\
\hline мъхницин $\left(2^{\mathrm{r}} / 2, \mathrm{r} .14\right)$ & мх хннццн $\left(2^{\mathrm{r}} / 2, \mathrm{r} .14\right)$ \\
\hline сп'ммхнтА $\left(2^{v} / 1\right.$, r. 1$)$ & спвм'́́̈нта $\left(2^{\mathrm{v}} / 1, \mathrm{r} .1\right)$ \\
\hline Súw. $\left(2^{\mathrm{v}} / 1, \mathrm{r} .24\right)$ & కúwa $\left(2^{\mathrm{v}} / 1, \mathrm{r} .24\right)$ \\
\hline
\end{tabular}

c) whole word $v$ s. shorthand/letter written above the row:

\begin{tabular}{|c|c|}
\hline E $1697 \mathrm{v}$ & E 1697 I/B \\
\hline Проро́кل̌si $\left(2^{\mathrm{r}} / 1, \mathrm{r} .6\right)$ & ]$_{\text {ppis }}^{\widehat{\rho}} \gamma_{1 \mathrm{~b}}\left(2^{\mathrm{r}} / 1, \mathrm{r} .6\right)$ \\
\hline 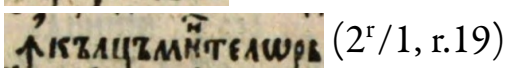 & 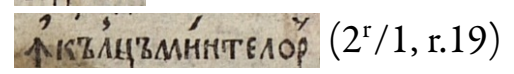 \\
\hline
\end{tabular}

${ }^{5}$ The goals envisaged so far regarding the research of the work of Antim Ivireanul (or of some broader issues) have not led to the highlighting, until now, of this fact: see BRV I, loc. cit.; Ștrempel (1997); Chițulescu (2016); etc. 
мормй

пх์ Нัสย $\left(2^{\mathrm{v}} / 1, \mathrm{r} .27\right)$

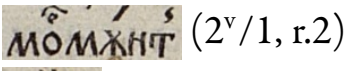

пाँ̈kе $\left(2^{\mathrm{v}} / 1, \mathrm{r} .27\right)$

d) different typographical organization of the row:

E $1697 \mathrm{~V}$ E 1697 I/B

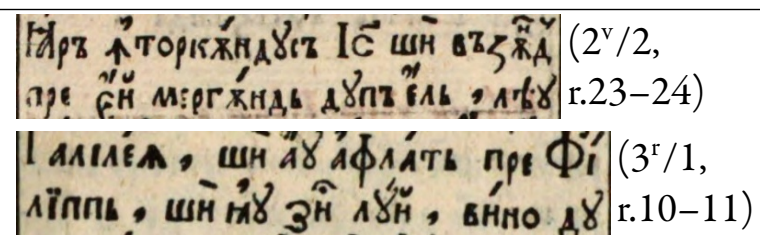

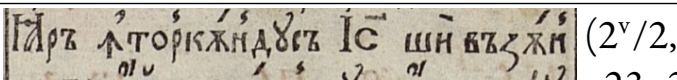

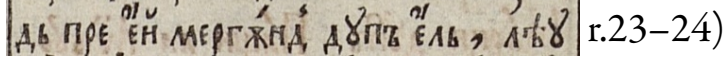

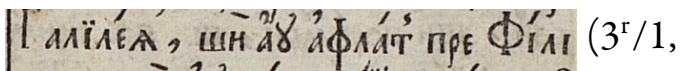

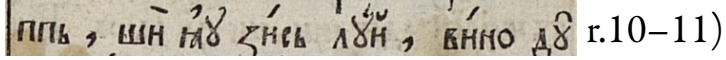

e) differences in the involvement of diacritic signs and/or graphic signs without phonetic value:

\begin{tabular}{|c|c|}
\hline E 1697 V & E 1697 I/B \\
\hline 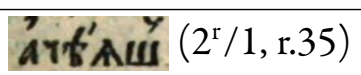 & àt'́tus $\left(2^{r} / 1, r .35\right)$ \\
\hline 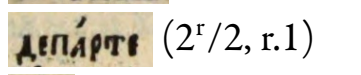 & Aвппарте $\left(2^{\mathrm{r}} / 2, \mathrm{r} .1\right)$ \\
\hline Oर/ & 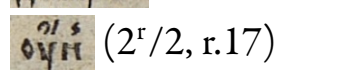 \\
\hline
\end{tabular}

Apart from this type of changes made at a given time, there are also some-much fewer-that concern the actual use of the language at another level, namely different phonetic forms of the same linguistic unit:

\begin{tabular}{ll}
\multicolumn{1}{c}{$1697 \mathrm{v}$} & \multicolumn{1}{c}{$\mathrm{E} 1697 \mathrm{I} / \mathrm{B}$} \\
\hline sculindu-se $\left(2^{\mathrm{r}} / 1, \mathrm{r} .29\right)$ & sculindu-s $\breve{a}\left(2^{\mathrm{r}} / 1, \mathrm{r} .29\right)$ \\
Isaia $\left(2^{\mathrm{r}} / 1, \mathrm{r} .6\right)$ & Isaiia $\left(2^{\mathrm{r}} / 1, \mathrm{r} .6\right)$ \\
luund $\left(2^{\mathrm{v}} / 1, \mathrm{r} .27\right)$ & luînd $\left(2^{\mathrm{v}} / 1, \mathrm{r} .27\right)$
\end{tabular}

Finally, on $7^{\mathrm{r}}$, three forms place together the $\mathrm{E} 1697$ I and v copies, on the one hand, and the E 1697 B copy, on the other:

\begin{tabular}{ll}
\multicolumn{1}{c}{$1697 \mathrm{I} / \mathrm{v}$} & \multicolumn{1}{c}{$\mathrm{E} 1697$ в } \\
\hline vășmînt $\left(7^{\mathrm{r}} / 1, \mathrm{r} .4\right)$ & veșmînt $\left(7^{\mathrm{r}} / 1, \mathrm{r} .4\right)$ \\
nimănui $\left(7^{\mathrm{r}} / 1, \mathrm{r} .18\right)$ & nimunui $\left(7^{\mathrm{r}} / 1, \mathrm{r} .18\right)$ \\
$\operatorname{sămn}\left(7^{\mathrm{r}} / 2, \mathrm{r} .18\right)$ & $\operatorname{semn}\left(7^{\mathrm{r}} / 2, \mathrm{r} .18\right)$
\end{tabular}

If the observed facts clearly show a process of returning in several stages on the editing of the text, its motivations remain unclear in some of the situations exposed above. In the process of printing the 1697 edition, the sheets $2^{\mathrm{r}-\mathrm{v}}$ and $3^{\mathrm{r}-\mathrm{v}}$ for example are reworked, although the nature and number of the resulting changes do not indicate an orientation determined by the judgment on the linguistic aspect of the text, as it happens-we believe-in the case of changes related to the grammar of the verb.

\section{Conclusions}

Regardless of the causes of the resumption of work on some portion of the text, the existence of typographical variants, capitalized in the final realization of the Gospel of Snagov, from 1697, highlights a complex and nonlinear editorial and typographical behavior.

The existence of differences between copies, of any type, also means that the results of the research of the text strictly for the purpose of its linguistic description will vary-even if to an extent that can be considered small-depending on the chosen copy (possibly incidentally) as the object of study. On the other hand, however, it is precisely the practice of the repeated embossing of the typographical object in situ that offers the modern linguist the chance to perceive not the language of the text, but the language that writes the text, emanating from someone's consciousness, which in this way, indirectly, reveals its applied judgment on what is in accordance with the linguistic habits of the era and of the place. 


\section{Bibliography}

\section{A. Sources}

E 1682 = Sfinta și dumnezăiasca Evanghelie, București.

E 1693 = Evanghelie greco-română, București.

E $1697=$ Sf[î]nta şi d[u]mnezeiasca Evanghelie, Snagov.

\section{B. References}

BRV I = Bianu, I. \& Hodoș, N. (1903). Bibliografia românéscă veche. 1508-1830. Tomul I, 1508-1716, Stabilimentul grafic J.V. Socec, Bucuresci, 1903.

Chiţulescu, P. (coord.) (2016). Antim Ivireanul. Opera tipografică, Institutul Cultural Român, [s.l.]. Frâncu, C. (2009). Gramatica limbii române vechi (1532-1780), Casa Editorială „Demiurg”, Iaşi.

Iova, M. (coord.). Catalogul colectiv al cărții românești vechi, Evanghelie. Snagov, 1697.

Pavel, E. (2012). Arheologia textului, Casa Cărții de Știință, Cluj-Napoca.

Ștrempel, G. (1997). Antim Ivireanul, Editura Academiei, București. 